\title{
Innovative Coatings of Metallic Alloys Used as Bioactive Surfaces in Implantology: A Review
}

\author{
Mariana Prodana ${ }^{1}$, Andrei Bogdan Stoian ${ }^{1}$ (D, Cristian Burnei ${ }^{2}$ and Daniela Ionita ${ }^{1, *(D)}$ \\ 1 Department of General Chemistry, Faculty of Applied Chemistry and Material Science, \\ University Politehnica of Bucharest, 313 Splaiul Independentei, 060042 Bucharest, Romania; \\ mariana.prodana@upb.ro (M.P.); andreibstoian@yahoo.com (A.B.S.) \\ 2 Clinical Department of Orthopedics and Traumatology II, Clinical Emergency Hospital, Calea Floreasca 8, \\ 014461 Bucharest, Romania; cristian.burnei@umfcd.ro \\ * Correspondence: daniela.ionita@upb.ro; Tel.: +40-21-4023-930
}

Citation: Prodana, M.; Stoian, A.B.; Burnei, C.; Ionita, D. Innovative Coatings of Metallic Alloys Used as Bioactive Surfaces in Implantology: A Review. Coatings 2021, 11, 649. https://doi.org/10.3390/ coatings11060649

Academic Editor: Seunghan Oh

Received: 25 April 2021

Accepted: 26 May 2021

Published: 28 May 2021

Publisher's Note: MDPI stays neutral with regard to jurisdictional claims in published maps and institutional affiliations.

Copyright: (c) 2021 by the authors. Licensee MDPI, Basel, Switzerland. This article is an open access article distributed under the terms and conditions of the Creative Commons Attribution (CC BY) license (https:// creativecommons.org/licenses/by/ $4.0 /)$.

\begin{abstract}
Metallic implants are widely used in the field of implantology, but there are still problems leading to implant failures due to weak osseointegration, low mechanical strength for the implant, inadequate antibacterial properties, and low patient satisfaction. Implant failure can be caused by bacterial infections and poor osteointegration. To improve the implant functionalization, many researchers focus on surface modifications to prepare the proper physical and chemical conditions able to increase biocompatibility and osteointegration between implant and bone. Improving the antibacterial performance is also a key factor to avoid the inflammation in the human body. This paper is a brief review for the types of coatings used to increase osseointegration and biocompatibility for the successful use of metal alloys in the field of implantology.
\end{abstract}

Keywords: metallic implants; orthopedic implants; modified surfaces; osseointegration; bone fixation; antibacterial properties; active surfaces; coating performance

\section{Introduction}

Inserting implants into living organisms must be carried out in accordance with the natural conditions of living systems; considering that the functionality of the human body is achieved through the normal activity of each physiological system, any organ dysfunction thus is transmitted to the whole living system [1]. Implants can partially or totally replace a damaged element of the body under the conditions of their acceptance by the host environment $[2,3]$. Among the metallic materials approved for use in medical practice (orthopedics and dentistry), the most frequently used are: stainless steels with small amounts of carbon (316L), Co-Cr alloys, such as Co-Cr-Ni-Mo, precious metal alloys, Ti and its alloys (TiAlV, TiAlVMoFe, and TiAlZr), and biodegradable alloys [4]. Improvement in the long-term utilization of implantable materials is achieved by modifying its surface exposed to physiological and biological environments [5]. In numerous studies, it has been observed that metallic biomaterials undergo a series of corrosion reactions in human body fluids. These reactions result in release of metallic ions, which are toxic at high concentrations. Metal implants have different compositions and various structures than human bone, thus, the healing process takes longer as the bone/implant interface forms more slowly [6]. Along with heat treatments, laser treatments are also employed for covering the surfaces of metal implants with thin layers; these are sometimes structured at micro- and nanolevel obtained by more sophisticated or simpler chemical and electrochemical techniques that are overall more efficient than the bare metal surface. The criteria for the inclusion of biocompatible materials in international standards for the selection of implantable materials for prostheses are based on their biocompatibility [7] and are as follows: 
- Chemical and electrochemical criteria: the implant material in human tissue must be inert and must not suffer corrosion (local or general) in relation to mechanical, chemical, and bacteriological stresses.

- The biological criterion is that the implant or particles on the implant surface should not release ions, atoms, or chemical compounds that have allergic, toxic, or carcinogenic effect.

- The mechanical criterion imposes the limits of the performance of resistance to fatigue to mechanical demands such as those to which the human body is subjected during life.

Respecting these criteria, the fields of use of metal implants are wide ranging, i.e., from pumps, implant and artificial valves, to artificial joints.

In 1958, a Swiss company introduced a set of instruments and implants using Cr-NiMo stainless steel as an implant material, and later, Branemark performed the osseointegration of Ti [8]. The advantages of the qualities offered by Ti and its alloys allowed the extension of their use [9], but the main disadvantage related to price still limits this extension. In this situation, the investigation of Co-Cr-Mo alloys, with improved compositions and/or surfaces covered with layers with superior performance for applications in orthopedics, dentistry, and stent materials, remains an important option in research with not only scientific but also social and economic motivations for applications in orthopedics and dentistry as well as for stent materials [10,11].

The properties and operating behavior of alloys in the Co-Cr-Mo system for implantology are influenced by a few factors, including the composition and type of technology used to obtain finished parts, processing, finishing, polishing, and possibly coating with additional ceramic or polymeric layers [12].

Regarding the influence of the composition, Co increases the modulus of elasticity, mechanical strength, and hardness of the alloy and ensures the fluidity of the molten metal. $\mathrm{Cr}$ improves corrosion resistance by passivating the surface due to the formation of stable oxides $\left(\mathrm{Cr}_{2} \mathrm{O}_{3}\right)$ and promotes the formation of carbides. Mo influences the physical properties, increases the hardness [13], and decreases the ductility of the alloys. It also plays a role in finishing the microstructure by reducing the size of crystalline grains [14].

$\mathrm{Mn}$ has a positive effect on mechanical properties and increases the ability of $\mathrm{Cr}$ to absorb nitrogen.

The biocompatibility of these alloys is a consequence of the presence of the oxide surface layer. In physiological and biological environments, the physical and chemical properties and interface processes of metal implants are determined by this layer of oxides and not by the metal on which it is formed [15]. The first interaction on implant exposure in tissues is of great importance in the clinical success of implant integration. Research on the microscopic structure of tissues (histological information) demonstrates that tissue-implant interactions take place between oxides on the surface of the metal implant and tissue, and not between the metal surface and tissue [16].

To increase and improve the mechanical, chemical, and biological (biocompatibility, antimicrobial, and drug release) performances of metallic implants, a multitude of coatings have been proposed and investigated [17]. Functional coatings such as calcium phosphate coatings [2], titanium oxides [18], composite coatings [19], multilayer coatings [20,21], polymeric coatings [22], or antibacterial coatings [23] were used by surface modification techniques. In this review, the purpose of developing these types of coatings and the recent progress made on this subject is of interest, because the creation of bioactive surfaces is the mandatory condition for osseointegration of implants in tissue [24].

In this review, we recapitulate the main types of coatings on metal implants existing in the literature that are used to increase the implant biocompatibility, to obtain osseointegration, and to obtain a good antibacterial activity. The main categories of coatings mentioned in this review as well as some advantages and disadvantages are summarized in Table 1. 
Table 1. Coating Types and Their Properties.

\begin{tabular}{|c|c|}
\hline Coatings & Properties (Advantages and Disadvantages) \\
\hline Hydroxyapatite and calcium phosphate & $\begin{array}{ll}- & \text { Very good osteointegration; } \\
\text { - } & \text { Good bioactivity and biodegradability; } \\
\text { - } & \text { Weak mechanical properties; } \\
\text { - } & \text { Used as bone graft materials; } \\
\text { - } & \text { Chemical and mechanical properties such as the major inorganic } \\
& \text { Component of bone; } \\
\text { - } & \text { High solubility and bioresorbability; } \\
\text { - } & \text { Promotes cell growth and bone growth on the implant surface; }\end{array}$ \\
\hline $\mathrm{TiO}_{2}$ and valve metal oxides & $\begin{array}{l}\text { - } \quad \text { Promote osteointegration; } \\
\text { - } \quad \text { Resistant to corrosion; } \\
\text { - } \quad \text { Does not show osteoconductivity; } \\
\text { - } \quad \text { If it is thick and dense, then it shows biocompatibility; } \\
\text { Can absorb } \mathrm{Ca}^{2+} \text { ions and phosphate groups forming at the } \\
\text { bone-implant interface-the nucleation sites for bone-like apatite } \\
\text { (carbonated hydroxyapatite); } \\
\text { - Favors the adsorption of proteins; } \\
\text { - } \quad \text { Hardness for coating is 5.5-6.6 GPa, modulus of elasticity of } 259 \mathrm{GPa} ; \\
\text { - Increase bioactivation; }\end{array}$ \\
\hline $\begin{array}{l}\text { Composite (metal oxide formed on the surface } \\
\text { natively with ceramics: } \mathrm{ZrO}_{2}, \mathrm{TiN}, \mathrm{TiO}_{2}, \mathrm{SiO}_{2} \text {, and } \\
\mathrm{SiC} \text {; various thin multicomponent coatings) }\end{array}$ & $\begin{array}{ll}\text { - } & \text { High strength; } \\
\text { - } & \text { Excellent fatigue and tensile strength; } \\
\text { - } & \text { Superior corrosion and wear resistance; } \\
\text { - } & \text { Hood biocompatibility and bioactivity; } \\
\text { - } & \text { Elastic modulus of } 220 \mathrm{GPa} ; \\
- & \text { Coefficient of friction between } 0.11 \text { and } 0.19 ; \\
- & \text { Excellent biocompatibility; } \\
- & \text { High adhesion to the substrate; } \\
- & \text { Strength and mechanical strength; } \\
- & \text { Elastic modulus and reduced wear and friction; }\end{array}$ \\
\hline Multilayer & $\begin{array}{l}\text { - } \quad \text { High adhesion resistance; } \\
\text { - } \quad \text { Adhesive strength higher than } 100 \mathrm{~N} ; \\
\text { - } \quad \text { Promote the growth of a new bone and the adjacent coating; } \\
\text { - } \quad \text { Increase in binding strength from } 14.2 \pm 3.1 \text { to } 23.1 \pm 3.4 \mathrm{MPa} ; \\
\text { - } \quad \text { Guod biocompatibility; }\end{array}$ \\
\hline $\begin{array}{c}\text { Antibacterial (loaded with antibiotics, loaded with } \\
\text { non-antibiotic organic bactericides, surface doped } \\
\text { with inorganic bactericides, and adhesion } \\
\text { resistance surfaces) }\end{array}$ & $\begin{array}{ll}\text { - } & \text { Protect the host's defense system; } \\
\text { - } & \text { Achieve long-term implant fixation; } \\
\text { - } & \text { Minimize implant-associated infection; }\end{array}$ \\
\hline Polymeric & $\begin{array}{l}\text { - } \quad \text { Biocompatible; } \\
\text { - } \quad \text { Facilitate the biological fixation of the implant in the human body; } \\
\text { - } \quad \text { Promote osteointegration; } \\
\text { - } \quad \text { Promote cell proliferation; } \\
\text { Facilitate cell proliferation, tissue repair and growth, and the delivery } \\
\text { of biomolecules; } \\
\text { - } \quad \text { Biodegradable. }\end{array}$ \\
\hline
\end{tabular}




\section{Surface Modification: Coatings to Increase Bioactivity and Biocompatibility}

\subsection{Coatings with Hydroxyapatite and Calcium Phosphate}

Osteointegration represents a continuous, structural, functional, and coexistent symbiotic relationship between differential and appropriately remodeled biological tissues and components obtained synthetically from materials (implants) with specific clinical functions accepted by the body without initiating any rejection mechanism. In practice, osseointegration represents the process or mechanism of anchoring a non-vital component (implant) in a bone from a living organism that remains for a long time unchanged even under mechanical stress. An implant is considered osseointegrated when there is no relative progressive displacement between the implant and the bone with which is in direct contact.

Bioactivity is the characteristic of a biomaterial (used in making an implant) to form a connection with living adjacent tissues [25]. A layer of bioactive material must meet two conditions: to develop a positive biological interaction and induce the growth of bone tissue in the periphery, in order to achieve a bone-implant connection. The biological activity of the bioactive material [26] should be moderate, since too rapid growth of bone tissue causes a chaotic development of bone components, with the formation of cavities and structures that are not properly interconnected. In the long run, appearance of infection and resistance to the development of bone in some areas is possible.

The integration of an implant with a bioactive surface in the bone [27] is realized through multiple interfaces due to several cationic species.

The mechanism of osseointegration is presented schematically in Figure 1 for a bioinert and a bioactive implant. Immediately after surgery, the implant surface is surrounded by blood. Healing occurs for several weeks after the intervention. During this time, new bone is formed from the remaining hematoma via the formation of callus. These processes happen in the presence of both implant types. However, in the case of the bioactive implant, the additional ions present on the surface accelerate and favor the formation of more and denser bone tissue. Additionally, the phosphate coating produces a rougher implant surface that increases the surface contact with the bone.

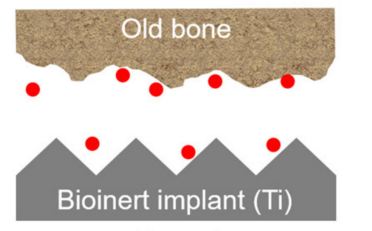

$1^{\text {st }}$ week

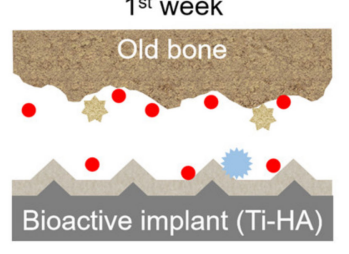

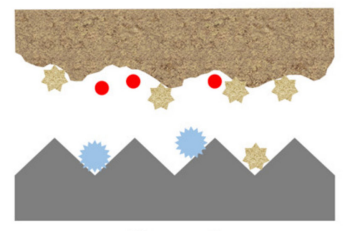

$4^{\text {th }}$ week

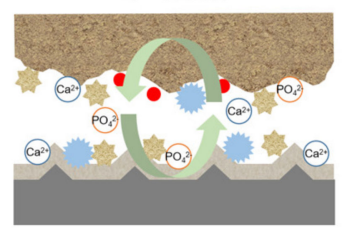

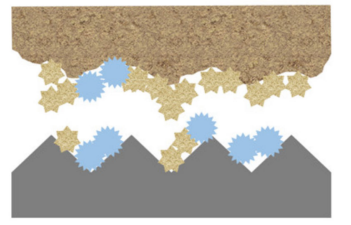

$8^{\text {th }}$ week

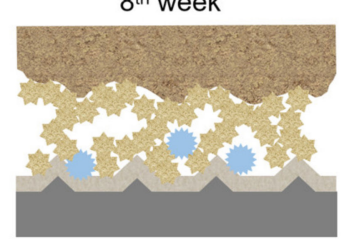

Blood cell

New bone

Protein

Ion

transfer

Figure 1. Schematic representation of implant osseointegration for bioinert and bioactive implants.

Interfaces rich in calcium phosphates, over time and under certain chemical and temperature conditions in the environment, can turn into hydroxyapatite, responsible for attracting cells together thus performing bone reconstruction [28]. Calcium phosphate-based materials have become interesting for practice as potential candidates for the manufacture of implants in the human body. Otherwise, they are already used in dentistry for dental crowns, on account of special aesthetic appearance, high compressive strength, and no chemical reactions in contact with human body biofluids.

Calcium phosphates have long been used to make artificial bones, and recently, with the development of new manufacturing techniques, are used for the fabrication of whole implants or only as solid or porous coatings of metallic implants [29].

Calcium phosphates consist of three main chemical components: the cations calcium $\left(\mathrm{Ca}^{2+}\right)$, phosphorus $\left(\mathrm{P}^{5+}\right)$, and oxygen $\left(\mathrm{O}^{2-}\right)$, as part of phosphate anions. Due to the 
great diversity of combinations of oxides, calcium and phosphate (both in the presence or absence of water), calcium phosphate compounds are distinguished in terms of phosphate anion groups: ortho- $\left(\mathrm{PO}_{4}{ }^{3-}\right)$, meta- $\left(\mathrm{PO}_{3}{ }^{-}\right)$, pyro- $\left(\mathrm{P}_{2} \mathrm{O}_{7}{ }^{4-}\right)$, and poly- $\left(\left(\mathrm{PO}_{3}\right)_{n}{ }^{n-}\right)$ [29]. Dorozhkin et al. in 2007 [30] discusses about calcium orthophosphates, as they represent the major component of all calcified tissues in humans.

Referring to the atomic lattice, the calcium orthophosphate crystal contains $\mathrm{PO}_{4}$ groups that restore the stability of the structure. According to LeGeros in 1991 [31] and Wopenka and Pasteris in 2005 [32], calcium orthophosphate crystals are easily soluble in water and easily dissolve in acids but are insoluble in alkaline solutions. Calcium orthophosphates are a major inorganic constituent of the human skeleton, and they are also found in deer antlers and in some species of shells as well as in pathological forms (urinary stones, atherosclerotic lesions, or calcifications). In the biological system, they are present in the weakly crystallized state with hydroxyapatite substituted with $\mathrm{Na}^{-}, \mathrm{Mg}^{-}$, and non-stoichiometric carbonate-substituted ions, known as biological apatite. Calcium orthophosphate-based bioceramics have long been used clinically. Because to their weak mechanical properties, they are limited to the non-bearing component of the skeleton.

Eleven calcium orthophosphates are known to have different $\mathrm{Ca} / \mathrm{P}$ molar ratios, from 0.5 to 2.0. The main parameters that influence the properties of calcium orthophosphates are the molar ratio $\mathrm{Ca} / \mathrm{P}$, alkalinity or acidity, and their solubility in different solvents. The ratio between $\mathrm{Ca}$ and $\mathrm{P}$ also depends on the $\mathrm{pH}$ of the solution. Acidity and solubility in water increase inversely with the $\mathrm{Ca} / \mathrm{P}$ molar ratio [33].

Because of their similarity with biological apatite from chemical composition point of view, calcium orthophosphates such as hydroxyapatite (HA), amorphous calcium phosphate $(\mathrm{ACP})$, tricalcium phosphate $(\mathrm{TCP})$, and octocalcium phosphate $(\mathrm{OCP})$ have been used as bone graft materials [34,35].

Synthetically sintered hydroxyapatite has chemical and mechanical properties similar to the major inorganic component of bone and can bind strongly to bone [36,37].

The higher solubility of calcium orthophosphates facilitates the stimulation of bone regeneration with several $\mathrm{Ca}$ and $\mathrm{P}$ ions.

$\beta$-TCP and $\alpha$-TCP are the most popular materials for making bone scaffolds that are designed to support bone regeneration [38], because they have higher bioresorbability than HA due to their higher solubility in physiological fluid. OCP has a structure similar to HA and is a precursor of HA [38].

Unlike HA, OCP possesses osteoinductivity and the ability to generate bone tissue $[39,40]$.

Suzuki et al. compared in vivo performance for OCP and HA by implanting these materials in a bone defect belonging to a rat, a study that was performed for 6 weeks [40].

After 6 weeks of implantation, it was found that the OCP was completely biodegraded, much more than HA or TCP. Implants made of OCP showed a maximum amount of bone tissue regeneration, which is extremely positive in its use not only as a source of calcium and phosphorus but also as a model for bone formation. Research into the clinical application of OCP is not fully known or studied, and therefore, many potential problems, such as from synthesis of OCP to bulk materials technology from OCP, need to be investigated. Despite the good bioactivity qualities of these families of calcium orthophosphates, the mechanical properties of those materials are not suitable for the supporting components of skeletons.

HA is mainly used as a coating material for implants, due to its lower solubility and higher crystallinity than other calcium orthophosphates.

HA can remain on the implant for a longer time and form a relatively firm bond with the substrate. After covering a metal implant with HA, it took only 20 days for a patient to recover from immobilization, to be able to move [41] and it took 100 days of recovery from immobilization for the empty metal implant [42].

Furlong and Osborn were the first research group to report the use of HA-coated implants for clinical trials [43]. 
According to a 10-year study, Yang et al. showed that HA coatings improved the clinical effect, and the implantation failure rate was less than $2 \%$ [44].

In the last 30 years, the application of HA on the surface of metal implants by PLD (plasma deposition) technique has determined their successful use in the field of dentistry and orthopedics.

During bone remodeling, the degradation of the HA sheath was observed due to the presence of osteoclastic activity $[45,46]$.

During the bone remodeling process, the HA coating was replaced with bone and the result was the loss of this HA coating.

However, there is still much controversy regarding the coverage of dental and orthopedic implants with HA.

Research on HA and Ca and P-based coatings has focused on both the coating itself and the optimization of this process in order to obtain a maximum tissue response [47,48].

Regarding HA coatings on implants, the Food and Drug Administration (FDA) and the International Organization for Standardization (ISO) have established guidelines for minimum requirements for HA coatings [44,47].

HA and Ca phosphates, obtained by different methods, have thicknesses that can vary from submicron to several hundred microns; thickness being an important parameter in terms of the stability over time of the implant, the mechanical properties of the coatings must be considered. Ca phosphates have poor mechanical strength when the layer is too thick and mechanical fractures can occur. If the coating is too thin, the Ca phosphate layer has a risk of dissolving and then the bioactivity of the implant is affected. Although HA has the second lowest solubility among Ca orthophosphates, it has been reported that it could be resorbed by approximately 15-30 $\mu \mathrm{m}$ annually [49]. Several aspects related to mechanical strength, bioactivity, chemical stability, and long-term fixation were considered to obtain the optimal properties of HA and Ca phosphate coatings for implants (Table 2).

Table 2. HA Coating Requirements [44].

\begin{tabular}{cc}
\hline Property & Specification \\
\hline Thickness & $5-70 \mu \mathrm{m}$ \\
\hline Crystallinity & $62 \%$ minimum \\
\hline Phase purity & $95 \%$ minimum \\
\hline Ca/P ratio & $1.67-1.76$ \\
\hline Density & $2.98 \mathrm{~g} / \mathrm{cm}^{3}$ \\
\hline Heavy metals & $<50 \mathrm{ppm}$ \\
\hline Tensile strength & $>50.8 \mathrm{MPa}$ \\
\hline Shear strength & $>22 \mathrm{MPa}$ \\
\hline Abrasion & Mass loss $<65 \mathrm{mg}$ at 100 cycles \\
\hline
\end{tabular}

Another important parameter to consider is the adhesion of coatings with HA and Ca phosphates. In order to have a good reliability of the coating process, the adhesion that must be satisfactory to the adjacent substrate must be taken into account. Hence, to evaluate the adhesive performance, tensile adhesion test (TAT), according to ASTM C633, was performed. It has been reported in the literature that the adhesion strength of HA coatings obtained by plasma spraying is in the range of 20-30 MPa [50-52], although, according to TAT, in industry, a typical resistance to adhesion is in the range of 10-15 MPa. A few literature studies have addressed this topic. The disadvantage of the TAT method is that the mechanical damage of the coating occurs inside the thick coatings and not at the interface between the coating and the substrate. The defects appear unevenly distributed on the surface and a local defect appears in the layer. 
For very thin or very porous coatings, the adhesive used to anchor the stretching devices can penetrate the layer and adhere directly to the substrate. For this reason, the measured adherence is not a real one [53]. Other methods for determining adhesion strength at the interface between implant and HA coating, such as determining fracture resistance [52] and using laser for shock adhesion tests (LASAT), have been proposed [53].

Another important factor when talking about HA coatings is related to their crystallinity, which influences both stability and bioactivity [54]. It is recommended, to maintain the adhesion resistance between the implant and the coating, that structures without resorption or with a reduced one that usually have high crystallinity be used for clinical trials. This statement contradicts the fact that the ideal interface between the coating and the surrounding tissue must match the replaced tissue. It is considered that the crystallinity of the HA coating is the most important factor for the bioactivity of the HA coating. The coating should have low crystallinity but may weaken the bond strength between layer and substrate in vivo. The initial processes that take place on the surface covered with HA after implantation involve the dissolution of the coating. It is recommended that these coatings should be less crystalline and thus more resorbable to promote the bone growth [55].

Tsui et al. concluded that the ideal HA coating should have a dense structure, with strong cohesion strength, low porosity, substrate adhesion, high degree of crystallinity, high chemical purity, and phase stability [52]. However, so far, there are no techniques to determine the perfect coatings, without pores, without cracks, or without secondary phases. All these "defects" can cause problems related to the durability of the implant and the dissolution of the coating in the physiological fluid. However, in 11-year clinical trials, satisfactory results have been reported for elderly patients (approximately, 53 years) who have undergone primary arthroplasty using HA-coated implants [45].

\subsection{Coatings with $\mathrm{TiO}_{2}$}

Ti oxides are used to promote osteointegration [56] and are classified into rutile, anatase, and brookite if their crystalline structure is considered. At low temperatures, the brookite turns into rutile. For this reason, only anatase and rutile are of interest. Ti and its alloys oxidize easily in air and form a layer of $\mathrm{TiO}_{2}$ on the surface of the metal. This layer is called native, has thicknesses between 3 and $7 \mathrm{~nm}$, and contains the amorphous phase. Native oxide provides very good chemical stability manifested by increased corrosion resistance [57]. The concentration ratio between Ti and O gradually varies from 1 to 2 [58]. $\mathrm{Ti}$ and its alloys are stable and resistant to corrosion; however, the literature has considered the amount of $\mathrm{Ti}$ ions that can be released in the tissues adjacent to the metal implant used [59]. The release of Ti ions into tissues indicates that its corrosion has occurred in vivo. Native $\mathrm{TiO}_{2}$ is bioinert and cannot promote a direct link with living bone, which implies that $\mathrm{TiO}_{2}$ does not show osteoconductivity and osseointegration. To increase biocompatibility, the $\mathrm{TiO}_{2}$ layer needs to be thick and dense.

$\mathrm{TiO}_{2}$ has a molecule composed of a positive $\mathrm{Ti}^{+}$ion and two $\mathrm{O}^{2-}$ negative ions. When $\mathrm{Ti}$ is in contact with electrolyte solutions (body fluids, saliva, and plasma), $\mathrm{OH}^{-}$can easily bind to the Ti cation in the $\mathrm{TiO}_{2}$ and $\mathrm{Ti}-\mathrm{OH}$ groups. Acidic or basic Ti-OH groups can form on the surface of $\mathrm{Ti}[60]$.

$$
\begin{aligned}
& \text { Ti-OH (acidic hydroxide) }+\mathrm{H}_{2} \mathrm{O} \rightarrow[\text { Ti-O }]^{-}+\mathrm{H}_{3} \mathrm{O}^{+} \\
& \text {Ti-OH (basic hydroxide) }+\mathrm{H}_{2} \mathrm{O} \rightarrow\left[\text { Ti- } \mathrm{OH}_{2}\right]^{+}+\mathrm{OH}^{-}
\end{aligned}
$$

The $\mathrm{pH}$ of the electrolyte influences the charge on the Ti surface. When the $\mathrm{pH}$ is less than 4 , the Ti-OH groups will become $\left[\mathrm{Ti}^{-} \mathrm{OH}_{2}\right]^{+}$and will determine the positive charge of the surface.

For $\mathrm{pH}$ values above 9, Ti-OH yields a proton and forms the $[\mathrm{Ti}-\mathrm{OH}]^{-}$anion, and thus, the Ti surface is negatively charged. When the $\mathrm{pH}$ is between 4 and 9, Ti-OH is observed simultaneously in oxide, acid hydroxides, as well as basic hydroxides forms. 
The isoelectric point (IEP) of $\mathrm{TiO}_{2}$ is in the narrow range of $\mathrm{pH} 5-6$. It indicates the $\mathrm{pH}$ value of a solution where the net charge on the surface of $\mathrm{Ti}$ is zero.

Negatively charged surfaces can attract cations such as $\mathrm{Ca}^{2+}, \mathrm{Na}^{+}$, and $\mathrm{Mg}^{2+}$, whereas $\mathrm{H}_{2} \mathrm{PO}_{4}{ }^{-}$or $\mathrm{HPO}_{4}{ }^{2-}$ anions are attracted to the positively charged surface.

$\mathrm{TiO}_{2}$ can absorb $\mathrm{Ca}^{2+}$ ions and phosphate groups forming at the bone-implant interface, the nucleation sites for bone-like apatite (carbonated hydroxyapatite). This layer of apatite can trigger cell growth and bone growth on the implant surface, resulting in a good bone fixation (Figure 2). For these reasons, the modification of the $\mathrm{TiO}_{2}$ layer becomes a priority in the sense of increasing the biocompatibility and osseointegration of the $\mathrm{Ti}$ or $\mathrm{Ti}$ alloys implant materials.

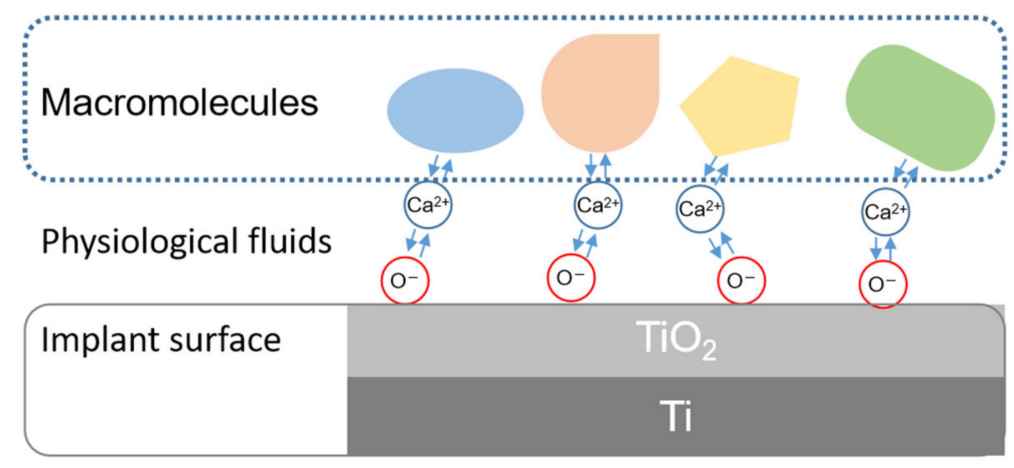

Figure 2. Possible mechanism for the initial adsorption of macromolecules on $\mathrm{Ti}$ implants. $\mathrm{TiO}_{2}$ has an overall negative charge at the interface with the physiological fluids. Ca attracts on the surface, and further, it binds to the macromolecules on the surface of the implant.

The $\mathrm{TiO}_{2}$ layer favors the adsorption of proteins or other electrically charged macromolecules. Protein attachment occurs immediately after implantation and is important for subsequent cell growth on the implant surface. Sunny and Sharma showed that the $\mathrm{TiO}_{2}$ layer obtained by anodic oxidation from a few nanometers to $200 \mathrm{~nm}$ showed a 7-fold increase in the albumin/fibrinogen protein absorption ratio [61]. Huang et al. reported that there is a 1.5-fold increase in coagulation time when the thickness of the $\mathrm{TiO}_{2}$ layer increases from 10 to $250 \mathrm{~nm}$ through a process of thermal oxidation [62]. Using a $\mathrm{TiO}_{2}$-coated $\mathrm{Ti}$ implant, inserted in a dog, Yang et al. showed that no thrombi formed on the surface and coagulation took place on pyrolytic isotropic carbon (LTI-carbon) [63].

$\mathrm{TiO}_{2}$ is also used to change mechanical properties, wear resistance, and corrosion resistance [64]. In terms of mechanical properties, the suggested hardness for coating is 5.5-6.6 GPa [65]. Various mechanical nano-indentation tests were performed to cover $\mathrm{Ti}$ with oxide at $600{ }^{\circ} \mathrm{C}$ obtaining a modulus of elasticity of $259 \mathrm{Gpa}$ and a hardness of $14 \mathrm{Gpa}$. Mandl et al. showed an increase in the average lifetime for an alloy based on $\mathrm{Ti}$ and $\mathrm{Ni}$ in case of its oxidation at $250{ }^{\circ} \mathrm{C}$ [66]. Chiu et al. approached a coating of a NiTi alloy by sol-gel technique, which determined the increase in corrosion resistance in Hank's solution compared to the substrate. [67].

Rohanizadeh et al. analyzed the production of $\mathrm{TiO}_{2}$ for in vivo deposition of hydroxyapatite [68].

There are four methods for making the $\mathrm{TiO}_{2}$ layer on $\mathrm{Ti}[69]$ :

1. heat treatment at $750{ }^{\circ} \mathrm{C}$ for $90 \mathrm{~min}$.

2. oxidation in $30 \% \mathrm{H}_{2} \mathrm{O}_{2}$ combined with subsequent heat treatment.

3. the method of coating by soaking/centrifuging with a rutile/gelatin.

4. anatase/gelatin suspensions.

The bioactivity of the substrates obtained after using the 4 types of treatment was followed by immersing the samples in calcium phosphate solution for 2 weeks. 
It was observed that the percentage of the area covered with hydroxyapatite in ascending order is: (4) submerged in anatase suspension> (3) submerged in rutile suspension> (2) treated with $\mathrm{H}_{2} \mathrm{O}_{2}>$ (1) heat treated > untreated [69].

The structure of the anatase and the rearrangement of Ti-OH can increase the attraction of calcium and phosphate ions by Ti-OH groups.

Uchida et al. reported that the network plane (001) of apatite fits crystallographically with the plane (110) of anatase, rather than with (101) the plane of the rutile [70]. The best crystallographic phase of anatase and apatite results from the hydrogen bond that is formed between the hydroxyl group of apatite and the oxygen of anatase. A smaller number of $-\mathrm{OH}$ groups were obtained on the heat-treated Ti surface. The adhesion resistance of apatite on the substrate of the treated samples is in ascending order as follows: (2) $\mathrm{H}_{2} \mathrm{O}_{2}$ treated $>$ (3) soaked in rutile suspension $>(1)$ heat treated $>(4)$ soaked anatase suspension $>$ untreated [69].

The excellent adhesion of the $\mathrm{H}_{2} \mathrm{O}_{2}$-treated samples is probably due to the presence of cracks. Such cracks provide the places of mechanical blockage between the apatite crystals and the Ti substrate, resulting in the adhesion of the apatite to the substrate.

Nanostructured $\mathrm{TiO}_{2}$ is the favorite subject lately for many researcher groups [71,72] due to the advantage of obtaining large specific area, to increase bioactivation [73-76].

\subsection{Composite Coatings}

To be used as implants, the materials must have high strength, excellent fatigue and tensile strength, superior corrosion and wear resistance, good biocompatibility, and bioactivity. Even if the metallic materials used in implantology can meet some of the mechanical requirements, their interfacial connection with the host tissue when they are introduced into the human body is weak, which can compromise the long-term fixation of the implant. As a result, the researchers' interests focused on obtaining biocompatible and bioactive multifunctional composites. Over the years, a wide variety of composite coatings have been obtained to increase the performance of stainless steel $[77,78]$ or metal alloys used in implantology $[19,79,80]$.

As a result, it was considered to mix the metal oxide formed on the surface natively with ceramics, namely $\mathrm{ZrO}_{2}, \mathrm{TiN}, \mathrm{TiO}_{2}, \mathrm{SiO}_{2}$, and $\mathrm{SiC}$. The best known and used ceramic is zirconia $\left(\mathrm{ZrO}_{2}\right)$, which began to be investigated in the late 1960s. Due to its excellent wear resistance, $\mathrm{ZrO}_{2}$ was used as a material for ball heads in artificial hip joints [81]. Composites with matte wear resistance, corrosion resistance, and good biocompatibility were obtained, which were used as applications in dental prosthesis, as components of the heart valve or for replacing the hip joint [82]. Obtaining composite coatings based on TiN and $\mathrm{TiO}_{2}$ has been shown to have excellent hemocompatibility [57].

Composite coatings formed of $\mathrm{TiO}_{2}$ and $\mathrm{SiO}_{2}$ can favor the formation of apatite in simulated body fluid (SBF) due to a negative charge on the surface owing to $\mathrm{pH}$ of body fluid [83].

Bolz and Schaldach have shown that, using amorphous SiC coatings, the biocompatibility of artificial heart valves has increased considerably [84]. The aim is to obtain composite coatings that offer the possibility of using them for a wide variety of biomedical applications.

Shtansky et al. followed various thin multicomponent coatings based on Ti-Ca-C-O(N), Ti-Zr-C-O-(N), and Ti-Nb-C-(N) [85]. Composites composed of TiC0.5 + CaO, TiC0.5+ $\mathrm{ZrO}_{2}$, and $\mathrm{TiC} 0.5+\mathrm{Nb} 2 \mathrm{C}$ were obtained.

The composite coatings Ti-Ca-C-O- $(\mathrm{N})$, Ti-Zr-C-O- $(\mathrm{N})$, and Ti-Nb-C-(N) showed a hardness between 30 and $39 \mathrm{GPa}$, the elastic modulus of $220 \mathrm{GPa}$. The friction coefficients were evaluated by the friction tests. The best coverage was the one with the composition Ti-Ca-C-O-(N), which had reduced coefficient of friction from 0.29 to 0.23 and showed no wear on the total sliding distance of $1000 \mathrm{~m}$ after 29,000 cycles. The Ti-Ca-C-O-(N) coatings did not show any wear generated until the completion of the tests at 10,000 cycles, and 
the coefficient of friction was measured from 0.16 to 0.22 . The coefficient of friction of the Ti-Nb-C- $(\mathrm{N})$ coatings was from 0.11 to 0.19 .

These composite coatings showed improved mechanical properties and wear resistance. Both in vitro and in vivo biocompatibility were evaluated, and after 16 weeks of subcutaneous implantation, the evaluation of the seeded cell population on the Teflon plates coated with Ti-Ca-C-O- $(\mathrm{N})$ and Ti-Zr-C-O- $(\mathrm{N})$ layers revealed that these coatings were very biocompatible and without any inflammatory reactions in mice.

Composites containing Ti-Nb-C-(N) layers with epithelial cites and fibroblasts cultured on them showed disturbed actin cytoskeleton. As a result, Ti-Ca-C-O-(N) and Ti-Zr-C-O$(\mathrm{N})$ are the two promising candidates of tribological coatings in which they can be applied to artificial joints and teeth.

In general, multicomponent Ti-based coatings with adjustable composition and structure are of great importance because they offer excellent biocompatibility, high adhesion to the substrate, mechanical strength, and elastic modulus and reduced wear and friction [86].

An extremely important factor related to the long-term durability of implants is the resistance to the interfacial connection between the coating and the substrate. The metal phase can be introduced in the process of depositing the composite coating. This metal phase is an intermediate coating or a second phase (continuous or dispersed) in the HA matrix, to strengthen the interfacial bond. Zheng et al. demonstrated that the inclusion of Ti in HA could result in increased adhesion resistance of plasma coatings [87].

Our research group elaborated a complex ceramic coating on Ti plates, containing $\mathrm{TiO}_{2}$ nanotubes, carboxylate multiwalled carbon nanotubes (MWCNTs-COOH), and hydroxyapatite, by electrodeposition. The research led to a new hybrid material, which can be used in biomedical applications, with improved characteristics. MWCNTs induced an increase in microhardness and the hemolytic index, indicating a better biological adhesion, and further, the osteoblasts response confirmed these observations [88-90].

The researchers' interest was extended to obtain nanocomposite materials, with new and high-performance properties, composed of polymers doped with various nanoparticles required in dentistry, e.g., $\mathrm{PMMA}$ doped with $\mathrm{TiO}_{2}$ nanoparticles [91].

\subsection{Multilayer Coatings}

To be successful in the long run, the coatings of metal implants must have not only a good biocompatibility but also a high adhesion resistance. Dual [88] or multilayer coatings are used that had promising results in terms of biocompatibility. The double layer of $\mathrm{HA} / \mathrm{ZrO}_{2}$ showed a bond strength of $39.8 \pm 6.2 \mathrm{MPa}(p<0.05)$, while for $\mathrm{HA}$, a single layer was $28.1 \pm 4.3 \mathrm{MPa}$ [92]. Narayan introduced between the HA-metal coating a layer of DLC interface obtained by the pulsed laser method at room temperature, thus obtaining HA adhesion to metal alloys [93]. Sun determined that the adhesive strength of the $\mathrm{TiN} / \mathrm{ZrO}_{2}$ multilayer coating was rated to be greater than $100 \mathrm{~N}$.

To increase the bonding resistance of the coating to the metal substrate, the grading of the composition of the material at the interface is used. It is known that the existence of defects, cracks, and discontinuities at the interface between the coating substrate comes from the difference in thermal expansion coefficients (CTE) for these materials. A graduated intermixed layer with CTE between the CTEs of the substrate and the CTE of the coating will be introduced to reduce the stresses induced due to the mismatch of the CTEs. Gradual coatings are obtained that do not give rise to so many fractures. The result is a stronger adhesion, the outer layer of the coating being created to promote the growth of a new bone and the adjacent coating favoring a high resistance to binding.

A buffer layer is formed between these two layers (from the surface and adjacent), which possess intermediate properties. Chen et al. obtained multilayer coatings of hydroxyapatite/titanium composed of an underlying Ti-bonded layer, an intermix layer and an outer HA layer on Ti alloys, using plasma spraying [94]. By varying the different deposition parameters, a strict control was obtained from the composition point of view 
for the multilayer coating. They have a remarkable increase in binding strength from $14.2 \pm 3.1$ to $23.1 \pm 3.4 \mathrm{MPa}$.

After 1 million cycles of cyclic fatigue of the multilayer coating, the adhesive strength of the graded coatings after fatigue testing $(\approx 22 \mathrm{MPa})$ was not abruptly deteriorated compared to the graded coatings before fatigue testing. However, monolayer coatings with HA decreased to $10.9 \mathrm{MPa}$.

Inagaki et al. obtained HA/Ti composite coatings with different compositions, synthesized by plasma deposition, by changing the RF power during laser deposition determining that the breaking strength can be increased by increasing the plasma strength due to the increase in the coating density [95].

In vitro studies have shown improved biocompatibility of multilayer coatings. Braic et al. performed cell response studies on multilayer Ti/TiAlN coating. Research has revealed good biocompatibility through cell density, cell morphology, and cell viability [96]. It has been shown that a larger number of cells attach to the $\mathrm{Ti} / \mathrm{ZrO}_{2}$ surface than to the bare surface [92] and they also successfully attach and spread on the surface of the $\mathrm{HA} /$ multilayer coating, confirming the previous result that $\mathrm{HA} / \mathrm{ZrO}_{2}$ possesses superior biocompatibility.

\subsection{Antibacterial Coatings}

Implant infection due to bacteria is a serious problem that can lead to several side effects and even death. However, no matter how well controlled the surgical procedures are, the bacteria can also be seen in traumatic surgery. The presence of bacteria on the surface of the implant can cause the formation of biofilms that protect the underlying bacteria from the host's defense system and antibacterial substances.

The metal implants used to replace the hard tissues were fixed with PMMA cement loaded with antibiotics. However, cemented fixations cause undesired effects and osteoconductive apatite layers have been successfully applied to the implant to achieve long-term implant fixation.

The incidence of infection in orthopedic surgeries is about $10 \%$ for fracture fixators and $85 \%$ for external fixators.

Although it has been reported that only $1-2 \%$ is the rate of infection observed in total hip arthroplasties, the actual figures are high and have increased with an aging population.

Antibacterial coatings have been widely researched to minimize implant-associated infection. The simplest method to prevent infection is to avoid the adhesion of bacteria and their subsequent colonization.

To evaluate the antibacterial properties for implantable alloys, the use of Gramnegative pathogenic bacteria such as Pseudomonas aeruginosa and Gram-positive Staphylococcus aureus was required. The methods used were aimed at determining the degree of inhibition, determining the colony forming units, CFU, and the halo method [71,88,97,98]. HA coatings or $\mathrm{TiO}_{2}$ coatings on Ti alloys put in evidence that the inhibition rate is higher for coatings compared with uncovered metallic alloys.

Various research in the field of antibacterial coatings have been carried out on a large scale [99]. An advantage of these coatings is the provision of local therapeutic agent. Bacterial killing agents, such as antibiotics [100], phenols [101], and heavy metals [102-104], were incorporated in the antibacterial coatings by spraying or soaking and capturing the hydrogel $[105,106]$. Chemical changes in coatings have been investigated to give the medical device the ability to kill bacteria on contact [107].

Osteoconductive materials, such as apatite, are preferable carrier materials because they can improve the bioactivity of implants. Usually, antibacterial coatings are grouped into 4 classes: coatings loaded with antibiotics, coatings loaded with non-antibiotic organic bactericides, surface doped with inorganic bactericides, and coatings with adhesion resistance. Depending on the nature of the bacterial habitat, coatings can be defined as either passive or active. 
Some of the coatings require a material containing antibacterial agents that degrade in a controllable manner to deliver antibiotics in a reasonable dose. Antibacterial coatings are grouped into 4 categories: antibiotic-laden coatings, non-antibiotic organic bactericideladen coatings, surface doped with inorganic bactericides, and adhesion-resistant coatings. Coatings can be defined as either passive or active. A selection of antibacterial coatings is presented in Figure 3. Antibiotic coatings are considered killing coatings. Antibiotics interfere with the metabolism of bacteria. Non-antibiotic organic bactericides are usually enzymes that can bind with the membrane of the bacteria, thus destroying it further. Biofilms are also destroyed with this method. Inorganic bactericide particles include a variety of usually metallic nanoparticles (e.g., Ag and $\mathrm{Cu}$ ) that produce reactive oxygen species (ROS). Surface architecture can kill bacteria by physically piercing their membranes. Nonkilling antibacterial surfaces include coatings of electrostatic repellants that interfere with the charge of the surface of the bacteria and low surface energy coatings that inhibit bacterial adhesion.
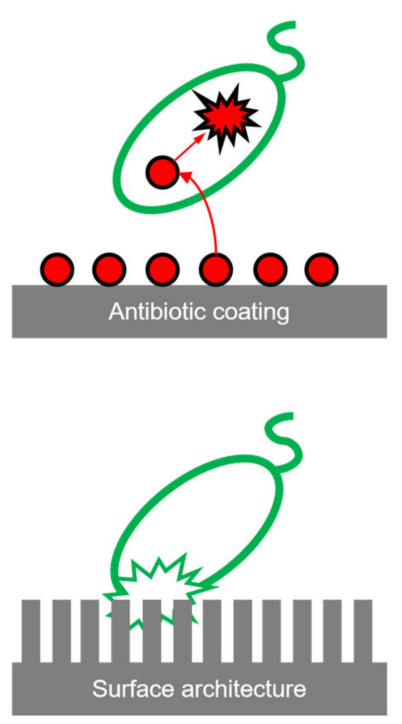
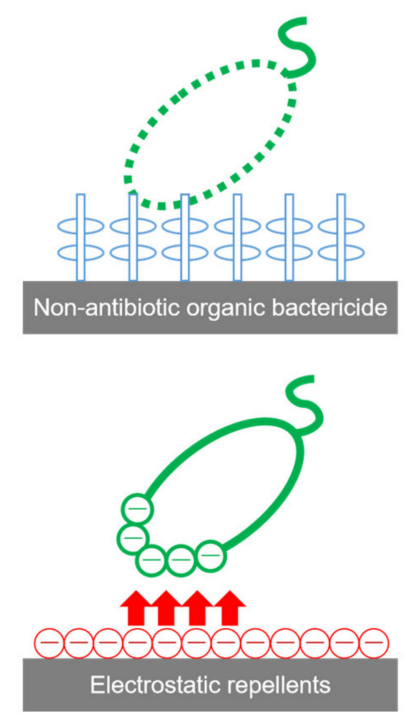
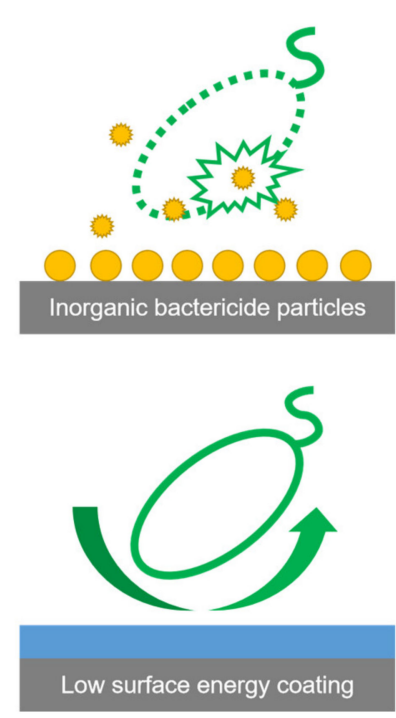

Figure 3. Schematic representation of some antibacterial coatings.

The incorporation of silver into the surface of the metal implant has been investigated for many years [108-110]. Instead of releasing bactericidal agents into tissues, some coatings can inhibit bacterial adhesion. The presence of a silver-based coating destroys the ability of bacteria to multiply. Silver nanoparticles bind to the bacterial cell wall and cell membrane [98,111-113].

It has failed to find widespread use due to the danger and unwanted toxicity problems induced by silver, so the amount of silver introduced into the body must be minimized using nanoparticles to maximize the active surface but control the amount. of Ag introduced into the body [114]. One of the advantages of antibacterial silver coatings is that it is unlikely to induce resistance to bacteria. Bacterial resistance to silver but also to antibiotics has been reported in a clinical case in which bacteria coexisted with silver particles [115].

The development of resistant bacterial strains due to improper and excessive use of antibiotics is the main driving force for research into the development of new antibacterial substances.

Methicillin-resistant Staphylococcus aureus (MRSA) is a bacterium that causes infections that are difficult to cure.

The efficacy of a peptide on MRSA killing in a rabbit species has been shown [116].

After carrying out some studies to increase the wettability of the Ti-6Al-4V surface, Ti-6Al-4V was obtained by UV irradiation treatment. A study determined the amount of reduced initial bacterial adhesion and the number of bacteria retained on the surface after passing through the two air-liquid interfaces [117]. Other antibacterial coatings 
release previously incorporated antibacterial substances, such as antibiotics, antiseptics, silver particles, and NO. Although these types of coatings showed antibacterial effects, the release took place only in a limited period, which is sufficient only to prevent early post-surgical infection. The main objective in the manufacture of these types of coatings is how to maintain the concentrations of the released substances at an efficient level, above the minimum inhibitory concentration (MIC) throughout the life of the implant. MIC indicates the minimum concentration of antibiotics dedicated to killing a certain type of bacterial strain.

Novelties have emerged regarding the development of intelligent coatings that provide bactericidal agents only when bacteria are attached to the coating [118,119].

Such passive coatings are highly preferred because they can be introduced inside the body for a relatively long time without local and side effects, while their antibacterial capacity can be maintained [120].

\subsection{Polymeric Coatings}

The polymer-based coatings are biocompatible and facilitate the biological fixation of the implant in the human body. With the help of these polymer-based coatings, the osseointegration process is facilitated, the possible infections related to the fixation of the metal implant being minimized. Using polymers, the interaction with the cellular material increases, forming a structural support for the formation of new tissue. Using polymeric materials, an increase in the corrosion resistance of biodegradable implants (such as $\mathrm{Mg}$ and its alloys) is also obtained [121].

The porous structure created using these types of coatings determines the optimal condition for cell proliferation.

Polymer coatings can be deposited on the surface of implantable materials not only by immersing them in various polymer solutions (dip-coating), by chemical vapor deposition (CVD), by spin-coating, by self-assembled monolayers, and layer-by-layer films but also by chemical grafting obtaining polymer brushes [122], by electrochemical polymerization, and electrophoretic deposition [123].

Some polymers are more commonly used in medicine due to their mechanical properties and their degradation rates (Table 3).

Table 3. Commonly used Polymers and Their Properties.

\begin{tabular}{cccc}
\hline Polymer & Chemical Formula & Properties & Degradation Rate \\
\hline PGA-polyglycolide [124] & $\mathrm{C}_{3} \mathrm{H}_{7} \mathrm{O}_{7} \mathrm{P}$ & $\begin{array}{c}\text { Aliphatic polyester, } \\
\text { Crystalline, semipermeable } \\
\text { aliphatic polyester, }\end{array}$ & 6-12 months \\
PLLA-polylactic acid [125] & $\left(\mathrm{C}_{3} \mathrm{H}_{4} \mathrm{O}_{2}\right)_{\mathrm{n}}$ & $\begin{array}{c}\text { crystalline, porous; rough looking } \\
\text { due to the open-pore structure }\end{array}$ & $>24$ months \\
PLGA-poly(lactic acid-co-glycolic acid) [126] & $\mathrm{C}_{5} \mathrm{H}_{8} \mathrm{O}_{5}$ & Semipermeable & $6-12$ months \\
PCL-polycaprolactone [127] & $\left(\mathrm{C}_{6} \mathrm{H}_{10} \mathrm{O}_{2}\right)_{\mathrm{n}}$ & Semipermeable, amorphous & $<12$ months \\
Collagen [128] & $\mathrm{C}_{65} \mathrm{H}_{102} \mathrm{~N}_{18} \mathrm{O}_{21}$ & Semipermeable & $1-9$ months \\
\hline
\end{tabular}

\subsubsection{Antifouling Coatings}

To attach bacteria to the surface of an implantable material, we must take into account the types of interactions that may be specific or nonspecific. Specific interactions take place through a protein.

The antifouling properties refer to coating of material with polymeric films capable of reducing protein adsorption. The antifouling properties satisfy the following functions: hydrophilicity, ability to form water bonds, and conformational flexibility [129].

The reduction in protein adsorption by antifouling polymers is due to a steric stabilizing force that has two major contributions, a volume component and a blending component. The volume component is highlighted by an elastic response due to decreased entropy when proteins are near the surface, in this case, the loss of freedom of movement of the 
polymer chain due to protein adsorption leads to protein repulsion. The blending/mixing component is caused by the reduced validity of the conformation of some segments of the molecule that lead to either compression or non-penetration of the protein chain $[130,131]$.

The polymers used for their weak fooling properties can be hydrophilic or zwitterionic polymers.

PEG as an antifouling polymer or PMMA forms hydrogen bonds with water $[132,133]$.

Zwitterionic polymers are molecules charged with positive and negative electrical charges, neutral from an electrical point of view, which form strong hydrogen bonds with water, giving the antifouling character $[134,135]$.

\subsubsection{Polymeric Cations}

Various types of cationic polymers destroy bacteria by damaging the cell membrane through a process called lysis, which causes the release of components inside the cell into the solution in which they are present. The adsorption of cationic polymers on the cell surface of the bacterium occurs due to the negative electrical charge of the bacterial membrane, the presence of teichoic acid protein in Gram-positive bacteria, or negatively charged phospholipids in Gram-negative bacteria. The polymer present on the surface of the metallic material used for implantation penetrates the cell membrane, thus, disturbing it [43]. Most cationic polymers contain quaternary ammonium, sulfonium, and phosphonium groups linked to the polymer chain [58,136-139]. In the case of $\mathrm{Ti}$, poly(hexamethylenebiguanadine) [140], pyrrole electropolymerization [141], and poly (ethylene imine) [142,143] were used.

\subsubsection{Biodegradable Polymer Coating}

Polymer coatings with various inorganic ions can facilitate cell proliferation, tissue repair and growth, and the delivery of biomolecules.

A group of researchers present a layer of polymer that is degraded in the body along with its carrier [144]. Scientists from the Karlsruhe Institute of Technology, the University of Michigan (Ann Arbor, MI, USA), and Northwestern Polytechnic University (Xi'an, China) have synthesized, for the first time, a polymer with biodegradable properties by CVD technique. The team applied the copolymerization of two special types of monomers: paracyclophanes commonly used for this method were combined with cyclic acetal ketones.

The degradation rate can be adjusted for the desired application. Using cell cultures, researchers have already shown that neither the polymer nor its degradation products are toxic [144].

Polymeric hybrid materials can be prepared as "smart" materials, using which functionality can be achieved through physical, chemical, or biological stimuli [145]. Biodegradable polymer coatings can prevent corrosion postimplantation [146,147].

For surface coatings, a wide varieties of biopolymers, such as polyvinylidene fluoride (PVDF), polymethyl methacrylate (PMMA), polypropylene (PP), polydimethylsiloxane (PDMS), polyurethane (PU), polylactic acid (PLA), poly(lactide-co-glycolic) acid (PLGA), polycaprolactone (PCL), and polyethylene (PE), were used; some natural polymers such as collagen and chitosan were also used for various biomedical applications $[146,148]$. Polymers such as poly(L-lactide-co-trimethylene carbonate) $\mathrm{P}(\mathrm{L} / \mathrm{TMC})$, poly(L-lactide-cotrimethylene carbonate-glycolide) $\mathrm{P}(\mathrm{L} / \mathrm{TMC} / \mathrm{G})$, and poly(D,L-lactide-glycolide) (PLGA) were used to obtain biodegradable coatings enriched with active substance (ciprofloxacin) formed on Ti6Al7Nb alloy [149], with biodegradation ability and drug-eluting properties as modified Ti implants.

A biodegradable polymer was used as a flexible covering for a breast implant; it contained one or more drugs for delivery at the surgical site, particularly for treating or preventing infection, pain, inflammation, capsular contracture, scarring or other complications associated with breast augmentation or breast reconstruction [150].

In addition, biodegradable polymers were used in dental tissue engineering and regeneration [151], which have replaced traditional non-degradable materials in maxillo- 
facial surgery, with application in bone regeneration and periodontal care, due to their ability to break down and be absorbed by the body without producing harmful degradation products, along with their great potential for controlled drug delivery, wound management, dental restorations, and tissue engineering.

\section{Conclusions}

In the last four to five decades, extraordinary progress has been made regarding the modification of metal surfaces for using them in implantology, considering the acceleration of osseointegration. The use of coatings to increase biocompatibility is extremely varied while achieving additional antibacterial effects. Coating treatments could have beneficial effects in terms of not only avoiding inflammation of the tissues adjacent to the implant and reducing the risk of infection but also improving the mechanical performance of the metal implant. The transition to nanocoatings has led to a progression of coatings by increasing the specific surface area and limiting any cytotoxic effects caused by certain metal ions. The topic of nanostructured coatings is a growing field that will further discover many benefits in restorative works for many decades.

Author Contributions: Writing-original draft preparation and organized the whole research, D.I.; designing the working approach and writing of the main aspects concerning the coatings of metallic implants, M.P. and A.B.S.; writing-review and editing, A.B.S. and C.B. All authors have read and agreed to the published version of the manuscript.

Funding: This research received no external funding.

Institutional Review Board Statement: Not applicable.

Informed Consent Statement: Not applicable.

Data Availability Statement: Data sharing not applicable.

Conflicts of Interest: The authors declare no conflict of interest.

\section{References}

1. Moreno, M.; Amaral, M.H.; Lobo, J.M.S.; Silva, A.C. Scaffolds for bone regeneration: State of the art. Curr. Pharm. Des. 2016, 22, 2726-2736. [CrossRef]

2. Su, Y.; Cockerill, I.; Zheng, Y.; Tang, L.; Qin, Y.-X.; Zhu, D. Biofunctionalization of metallic implants by calcium phosphate coatings. Bioact. Mater. 2019, 4, 196-206. [CrossRef]

3. Puleo, D.A.; Nanci, A. Understanding and controlling the bone-implant interface. Biomaterials 1999, 20, 2311-2321. [CrossRef]

4. Kumar, S.T.; Devi, S.P.; Krithika, C.; Raghavan, R.N. Review of metallic biomaterials in dental applications. J. Pharm. Bioallied Sci. 2020, 12, S14-S19. [CrossRef]

5. Xiao, M.; Chen, Y.; Biao, M.; Zhang, X.; Yang, B. Bio-functionalization of biomedical metals. Mater. Sci. Eng. C 2017, 70, 1057-1070. [CrossRef] [PubMed]

6. Dehghanghadikolaei, A.; Fotovvati, B. Coating techniques for functional enhancement of metal implants for bone replacement: A review. Materials 2019, 12, 1795. [CrossRef]

7. Reeve, L.; Baldrick, P. Biocompatibility assessments for medical devices—evolving regulatory considerations. Expert Rev. Med Devices 2017, 14, 161-167. [CrossRef]

8. Palmquist, A.; Lindberg, F.; Emanuelsson, L.; Brånemark, R.; Engqvist, H.; Thomsen, P. Morphological studies on machined implants of commercially pure titanium and titanium alloy (Ti6Al4V) in the rabbit. J. Biomed. Mater. Res. B Appl. Biomater. 2009, 91, 309-319. [CrossRef] [PubMed]

9. Priyadarshini, B.; Rama, M.; Chetan; Vijayalakshmi, U. Bioactive coating as a surface modification technique for biocompatible metallic implants: A review. J. Asian Ceram. Soc. 2019, 7, 397-406. [CrossRef]

10. Panagiotidou, A.; Meswania, J.; Hua, J.; Muirhead-Allwood, S.; Hart, A.; Blunn, G. Enhanced wear and corrosion in modular tapers in total hip replacement is associated with the contact area and surface topography. J. Orthop. Res. 2013, 31, 2032-2039. [CrossRef]

11. Omar, M.A.; Baharudin, B.-H.; Sulaiman, S. Stent manufacturing using cobalt chromium molybdenum (CoCrMo) by selective laser melting technology. In Proceedings of the 3rd Advanced Materials Conference, Kedah, Malaysia, 28-29 November 2016; p. 040001. [CrossRef]

12. Niinomi, M. Recent metallic materials for biomedical applications. Met. Mater. Trans. A 2002, 33, 477-486. [CrossRef]

13. Chen, Q.; Thouas, G.A. Metallic implant biomaterials. Mater. Sci. Eng. R Rep. 2015, 87, 1-57. [CrossRef] 
14. McHenry, M.E.; Laughlin, D.E. Magnetic properties of metals and alloys. In Physical Metallurgy, 5th ed.; Laughlin, D.E., Hono, K., Eds.; Elsevier: Oxford, UK, 2014; pp. 1881-2008.

15. Narushima, T. New-generation metallic biomaterials. In Metals for Biomedical Devices; Niinomi, M., Ed.; Woodhead Publishing: Cambridge, UK, 2010; pp. 355-378.

16. Hanawa, T. Titanium-tissue interface reaction and its control with surface treatment. Front. Bioeng. Biotechnol. 2019, 7, 170. [CrossRef] [PubMed]

17. Ionita, D.; Bajenaru-Georgescu, D.; Totea, G.; Mazare, A.; Schmuki, P.; Demetrescu, I. Activity of vancomycin release from bioinspired coatings of hydroxyapatite or TiO 2 nanotubes. Int. J. Pharm. 2017, 517, 296-302. [CrossRef]

18. Xia, W.; Grandfield, K.; Hoess, A.; Ballo, A.; Cai, Y.; Engqvist, H. Mesoporous titanium dioxide coating for metallic implants. J. Biomed. Mater. Res. B Appl. Biomater. 2012, 100, 82-93. [CrossRef] [PubMed]

19. Beig, B.; Liaqat, U.; Niazi, M.; Douna, I.; Zahoor, M.; Niazi, M. Current challenges and innovative developments in hydroxyapatitebased coatings on metallic materials for bone implantation: A review. Coatings 2020, 10, 1249. [CrossRef]

20. Chen, W.; Xu, K.; Tao, B.; Dai, L.; Yu, Y.; Mu, C.; Shen, X.; Hu, Y.; He, Y.; Cai, K. Multilayered coating of titanium implants promotes coupled osteogenesis and angiogenesis in vitro and in vivo. Acta Biomater. 2018, 74, 489-504. [CrossRef]

21. Vardaki, M.; Romonti, D.; Ionita, D.; Demetrescu, I. Polymeric hybrid coatings on Ti50\%Zr alloy. Mater. Plast. 2016, 53, 276-279.

22. Szaraniec, B.; Pielichowska, K.; Pac, E.; Menaszek, E. Multifunctional polymer coatings for titanium implants. Mater. Sci. Eng. C 2018, 93, 950-957. [CrossRef]

23. Romanò, C.L.; Tsuchiya, H.; Morelli, I.; Battaglia, A.G.; Drago, L. Antibacterial coating of implants: Are we missing something? Bone Jt. Res. 2019, 8, 199-206. [CrossRef]

24. Amengual-Peñafiel, L.; Brañes-Aroca, M.; Marchesani-Carrasco, F.; Jara-Sepúlveda, M.C.; Parada-Pozas, L.; Cartes-Velásquez, R. Coupling between osseointegration and mechanotransduction to maintain foreign body equilibrium in the long-term: A comprehensive overview. J. Clin. Med. 2019, 8, 139. [CrossRef]

25. Shi, Z.L.; Chua, P.H.; Neoh, K.G.; Kang, E.T.; Wang, W. Bioactive titanium implant surfaces with bacterial inhibition and osteoblast function enhancement properties. Int. J. Artif. Organs 2008, 31, 777-785. [CrossRef]

26. Jung, H.-D.; Jang, T.-S.; Wang, L.; Kim, H.-E.; Koh, Y.-H.; Song, J. Novel strategy for mechanically tunable and bioactive metal implants. Biomaterials 2015, 37, 49-61. [CrossRef]

27. Liu, Y.; Rath, B.; Tingart, M.; Eschweiler, J. Role of implants surface modification in osseointegration: A systematic review. J. Biomed. Mater. Res. A 2020, 108, 470-484. [CrossRef]

28. Jiang, X.; Yao, Y.; Tang, W.; Han, D.; Zhang, L.; Zhao, K.; Wang, S.; Meng, Y. Design of dental implants at materials level: An overview. J. Biomed. Mater. Res. A 2020, 108, 1634-1661. [CrossRef] [PubMed]

29. Eliaz, N.; Metoki, N. Calcium phosphate bioceramics: A review of their history, structure, properties, coating technologies and biomedical applications. Materials 2017, 10, 334. [CrossRef] [PubMed]

30. Dorozhkin, S.V. Calcium orthophosphates. Biomatter 2011, 1, 121-164. [CrossRef] [PubMed]

31. LeGeros, R.Z. Calcium phosphates in oral biology and medicine. Monogr. Oral Sci. 1991, 15, 1-201.

32. Wopenka, B.; Pasteris, J.D. A mineralogical perspective on the apatite in bone. Mater. Sci. Eng. C 2005, 25, 131-143. [CrossRef]

33. Dorozhkin, S.V. Calcium orthophosphates in nature, biology and medicine. Materials 2009, 2, 399-498. [CrossRef]

34. Ong, J.L.; Chan, D.C.N. Hydroxyapatite and their use as coatings in dental implants: A review. Crit. Rev. Biomed. Eng. 2000, 28, 667-707. [CrossRef]

35. Reid, J.W.; Pietak, A.; Sayer, M.; Dunfield, D.; Smith, T.J.N. Phase formation and evolution in the silicon substituted tricalcium phosphate/apatite system. Biomaterials 2005, 26, 2887-2897. [CrossRef] [PubMed]

36. Jarcho, M. Calcium phosphate ceramics as hard tissue prosthetics. Clin. Orthop. Relat. Res. 1981, 259-278. [CrossRef]

37. Jarcho, M.; Kay, J.F.; Gumaer, K.; Doremus, R.H.; Drobeck, H.P. Tissue, cellular and subcellular events at a bone-ceramic hydroxylapatite interface. J. Bioeng. 1977, 1, 79-92.

38. Kamitakahara, M.; Ohtsuki, C.; Miyazaki, T. Review paper: Behavior of ceramic biomaterials derived from tricalcium phosphate in physiological condition. J. Biomater. Appl. 2008, 23, 197-212. [CrossRef] [PubMed]

39. LeGeros, R.Z. Calcium phosphate-based osteoinductive materials. Chem. Rev. 2008, 108, 4742-4753. [CrossRef] [PubMed]

40. Suzuki, O.; Kamakura, S.; Katagiri, T. Surface chemistry and biological responses to synthetic octacalcium phosphate. J. Biomed. Mater. Res. B Appl. Biomater. 2005, 77, 201-212. [CrossRef] [PubMed]

41. Breme, J.; Zhou, Y.; Groh, L. Development of a titanium alloy suitable for an optimized coating with hydroxyapatite. Biomaterials 1995, 16, 239-244. [CrossRef]

42. Liu, D.-M.; Yang, Q.; Troczynski, T. Sol-gel hydroxyapatite coatings on stainless steel substrates. Biomaterials 2002, 23, 691-698. [CrossRef]

43. Furlong, R.; Osborn, J. Fixation of hip prostheses by hydroxyapatite ceramic coatings. J. Bone Jt. Surg. Br. Vol. 1991, 73-B, 741-745. [CrossRef]

44. International Organization for Standardization. Implants for Surgery-Hydroxyapatite_Part 2: Thermally Sprayed Coatings of Hydroxyapatite; International Organization for Standardization: Geneva, Switzerland, 2018. Available online: https://www.iso. org/standard/64617.html (accessed on 12 April 2021).

45. Geesink, R.G.T. Osteoconductive coatings for total joint arthroplasty. Clin. Orthop. Relat. Res. 2002, 395, 53-65. [CrossRef] 
46. Le Guéhennec, L.; Soueidan, A.; Layrolle, P.; Amouriq, Y. Surface treatments of titanium dental implants for rapid osseointegration. Dent. Mater. 2007, 23, 844-854. [CrossRef]

47. Sun, L.; Berndt, C.C.; Gross, K.A.; Kucuk, A. Material fundamentals and clinical performance of plasma-sprayed hydroxyapatite coatings: A review. J. Biomed. Mater. Res. 2001, 58, 570-592. [CrossRef] [PubMed]

48. Ionita, D.; Vardaki, M.; Stan, M.S.; Dinischiotu, A.; Demetrescu, I. Enhance stability and in vitro cell response to a bioinspired coating on zr alloy with increasing chitosan content. J. Bionic Eng. 2017, 14, 459-467. [CrossRef]

49. Gineste, L.; Gineste, M.; Ranz, X.; Ellefterion, A.; Guilhem, A.; Rouquet, N.; Frayssinet, P. Degradation of hydroxylapatite, fluorapatite, and fluorhydroxyapatite coatings of dental implants in dogs. J. Biomed. Mater. Res. 1999, 48, 224-234. [CrossRef]

50. Filiaggi, M.J.; Coombs, N.A.; Pilliar, R.M. Student research award in the undergraduate, Master candidate category, or health science degree candidate category, 17th annual meeting of the society for biomaterials, scottsdale, AZ may 1-5,1991. Characterization of the interface in the plasma-sprayed HA coating/Ti-6Al-4V implant system. J. Biomed. Mater. Res. 1991, 25, 1211-1229. [CrossRef] [PubMed]

51. Kurzweg, H.; Heimann, R.B.; Troczynski, T. Adhesion of thermally sprayed hydroxyapatite-bond-coat systems measured by a novel peel test. J. Mater. Sci. Mater. Electron. 1998, 9, 9-16. [CrossRef]

52. Tsui, Y.; Doyle, C.; Clyne, T. Plasma sprayed hydroxyapatite coatings on titanium substrates Part 1: Mechanical properties and residual stress levels. Biomaterials 1998, 19, 2015-2029. [CrossRef]

53. Guipont, V.; Jeandin, M.; Bansard, S.; Khor, K.A.; Nivard, M.; Berthe, L.; Cuq-Lelandais, J.-P.; Boustie, M. Bond strength determination of hydroxyapatite coatings on Ti-6Al-4V substrates using the LAser Shock Adhesion Test (LASAT). J. Biomed. Mater. Res. A 2010, 95, 1096-1104. [CrossRef] [PubMed]

54. Rahman, M.; Li, Y.; Wen, C. HA coating on Mg alloys for biomedical applications: A review. J. Magnes. Alloy. 2020, 8, 929-943. [CrossRef]

55. Kattimani, V.S.; Kondaka, S.; Lingamaneni, K.P. Hydroxyapatite-Past, present, and future in bone regeneration. Bone Tissue Regen. Insights 2016, 7, 36138. [CrossRef]

56. Greer, A.I.; Goriainov, V.; Kanczler, J.; Black, C.R.; Turner, L.-A.; Meek, R.M.; Burgess, K.; MacLaren, I.; Dalby, M.J.; Oreffo, R.O.; et al. Nanopatterned titanium implants accelerate bone formation in vivo. ACS Appl. Mater. Interfaces 2020, 12, 33541-33549. [CrossRef]

57. Huang, N.; Yang, P.; Leng, Y.; Chen, J.; Sun, H.; Wang, J.; Wang, G.; Ding, P.; Xi, T. Hemocompatibility of titanium oxide films. Biomaterials 2003, 24, 2177-2187. [CrossRef]

58. Liu, X.; Chu, P.K.; Ding, C. Surface modification of titanium, titanium alloys, and related materials for biomedical applications. Mater. Sci. Eng. R Rep. 2004, 47, 49-121. [CrossRef]

59. Browne, M.; Gregson, P. Effect of mechanical surface pretreatment on metal ion release. Biomaterials 2000, 21, 385-392. [CrossRef]

60. Kumar, S.G.; Rao, K.S.R.K. Polymorphic phase transition among the titania crystal structures using a solution-based approach: From precursor chemistry to nucleation process. Nanoscale 2014, 6, 11574-11632. [CrossRef] [PubMed]

61. Sunny, M.C.; Sharma, C.P. Titanium-protein interaction: Changes with oxide layer thickness. J. Biomater. Appl. 1991, 6, 89-98. [CrossRef]

62. Nan, H.; Chen, Y.-R.; Luo, J.-M.; Jin, Y.; Rong, L.; Jing, X.; Xue, Z.-N.; Liu, X.-H. In vitro investigation of blood compatibility of Ti with oxide layers of rutile structure. J. Biomater. Appl. 1994, 8, 404-412. [CrossRef]

63. Yang, P.; Huang, N.; Leng, Y.; Chen, J.; Sun, H.; Wang, J.; Chen, F.; Chu, P. In vivo study of Ti-O thin film fabricated by PIII. Surf. Coat. Technol. 2002, 156, 284-288. [CrossRef]

64. Mazare, A.; Totea, G.; Burnei, C.; Schmuki, P.; Demetrescu, I.; Ionita, D. Corrosion, antibacterial activity and haemocompatibility of TiO 2 nanotubes as a function of their annealing temperature. Corros. Sci. 2016, 103, 215-222. [CrossRef]

65. Kern, P.; Schwaller, P.; Michler, J. Electrolytic deposition of titania films as interference coatings on biomedical implants: Microstructure, chemistry and nano-mechanical properties. Thin Solid Films 2006, 494, 279-286. [CrossRef]

66. Mändl, S.; Fleischer, A.; Manova, D.; Rauschenbach, B. Wear behaviour of NiTi shape memory alloy after oxygen-PIII treatment. Surf. Coat. Technol. 2006, 200, 6225-6229. [CrossRef]

67. Chiu, K.; Wong, M.H.; Cheng, F.; Man, H. Characterization and corrosion studies of titania-coated NiTi prepared by sol-gel technique and steam crystallization. Appl. Surf. Sci. 2007, 253, 6762-6768. [CrossRef]

68. Rohanizadeh, R.; Al-Sadeq, M.; LeGeros, R.Z. Preparation of different forms of titanium oxide on titanium surface: Effects on apatite deposition. J. Biomed. Mater. Res. 2004, 71, 343-352. [CrossRef]

69. Marculescu, C.; Berbari, E.F.; Cockerill, F.R.; Osmon, D.R. Unusual aerobic and anaerobic bacteria associated with prosthetic joint infections. Clin. Orthop. Relat. Res. 2006, 451, 55-63. [CrossRef]

70. Uchida, M.; Kim, H.-M.; Kokubo, T.; Fujibayashi, S.; Nakamura, T. Structural dependence of apatite formation on titania gels in a simulated body fluid. J. Biomed. Mater. Res. 2003, 64, 164-170. [CrossRef] [PubMed]

71. Grecu, M.; Prodana, M.; Cimpean, A.; Ionita, D. Enhancing the performance of titanium surface via elaboration of a nanostructure and a bioactive coating. UPB Sci. Bull. B Chem. Mater. Sci. 2012, 74, 113-128.

72. Stoian, A.B.; Vardaki, M.; Ionita, D.; Enachescu, M.; Prodana, M.; Brancoveanu, O.; Demetrescu, I. Nanopores and nanotubes ceramic oxides elaborated on titanium alloy with zirconium by changing anodization potentials. Ceram. Int. 2018, 44, 7026-7033. [CrossRef] 
73. Kodama, A.; Bauer, S.; Komatsu, A.; Asoh, H.; Ono, S.; Schmuki, P. Bioactivation of titanium surfaces using coatings of TiO2 nanotubes rapidly pre-loaded with synthetic hydroxyapatite. Acta Biomater. 2009, 5, 2322-2330. [CrossRef]

74. Vardaki, M.; Pantazi, A.; Demetrescu, I.; Enachescu, M. Assessing the functional properties of TiZr nanotubular structures for biomedical applications, through nano-scratch tests and adhesion force maps. Molecules 2021, 26, 900. [CrossRef]

75. Vardaki, M.; Mohajernia, S.; Pantazi, A.; Nica, I.C.; Enachescu, M.; Mazare, A.; Demetrescu, I.; Schmuki, P. Post treatments effect on TiZr nanostructures fabricated via anodizing. J. Mater. Res. Technol. 2019, 8, 5802-5812. [CrossRef]

76. Pantazi, A.; Vardaki, M.; Mihai, G.; Ionita, D.; Stoian, A.B.; Enachescu, M.; Demetrescu, I. Understanding surface and interface properties of modified Ti50Zr with nanotubes. Appl. Surf. Sci. 2020, 506, 144661. [CrossRef]

77. Poorraeisi, M.; Afshar, A. Synthesizing and comparing HA-TiO2 and HA-ZrO2 nanocomposite coatings on 316 stainless steel. SN Appl. Sci. 2019, 1, 155. [CrossRef]

78. Sebastin, A.X.S.; Uthirapathy, V. In vitro electrochemical behavior of sol-gel derived hydroxyapatite/graphene oxide composite coatings on 316L SS for biomedical applications. ChemistrySelect 2020, 5, 12140-12147. [CrossRef]

79. Ziąbka, M.; Kiszka, J.; Trenczek-Zając, A.; Radecka, M.; Cholewa-Kowalska, K.; Bissenik, I.; Kyzioł, A.; Dziadek, M.; Niemiec, W.; Królicka, A. Antibacterial composite hybrid coatings of veterinary medical implants. Mater. Sci. Eng. C 2020, $112,110968$. [CrossRef] [PubMed]

80. Prashar, G.; Vasudev, H. Thermal sprayed composite coatings for biomedical implants: A brief review. J. Therm. Spray Eng. 2020, 2, 50-55. [CrossRef]

81. Piconi, C.; Maccauro, G. Zirconia as a ceramic biomaterial. Biomaterials 1999, 20, 1-25. [CrossRef]

82. Kola, P.; Daniels, S.; Cameron, D.; Hashmi, M. Magnetron sputtering of tin protective coatings for medical applications. J. Mater. Process. Technol. 1996, 56, 422-430. [CrossRef]

83. Li, P.; Ohtsuki, C.; Kokubo, T.; Nakanishi, K.; Soga, N.; De Groot, K. The role of hydrated silica, titania, and alumina in inducing apatite on implants. J. Biomed. Mater. Res. 1994, 28, 7-15. [CrossRef]

84. Bolz, A.; Schaldach, M. Artificial heart valves: Improved blood compatibility by PECVD a-SiC:H coating. Artif. Organs 1990, 14, 260-269. [CrossRef]

85. Shtansky, D.; Gloushankova, N.; Sheveiko, A.; Kharitonova, M.; Moizhess, T.; Levashov, E.; Rossi, F. Design, characterization and testing of Ti-based multicomponent coatings for load-bearing medical applications. Biomaterials 2005, 26, 2909-2924. [CrossRef]

86. Ionita, D.; Grecu, M.; Ungureanu, C.; Demetrescu, I. Antimicrobial activity of the surface coatings on TiAlZr implant biomaterial. J. Biosci. Bioeng. 2011, 112, 630-634. [CrossRef] [PubMed]

87. Zheng, X.; Huang, M.; Ding, C. Bond strength of plasma-sprayed hydroxyapatite/Ti composite coatings. Biomaterials 2000, 21, 841-849. [CrossRef]

88. Prodana, M.; Nistor, C.-E.; Stoian, A.B.; Ionita, D.; Burnei, C. Dual nanofibrous bioactive coatings on TiZr implants. Coatings 2020, 10, 526. [CrossRef]

89. Prodana, M.; Duta, M.; Ionita, D.; Bojin, D.; Stan, M.S.; Dinischiotu, A.; Demetrescu, I. A new complex ceramic coating with carbon nanotubes, hydroxyapatite and TiO2 nanotubes on Ti surface for biomedical applications. Ceram. Int. 2015, 41, 6318-6325. [CrossRef]

90. Prodana, M.; Ionita, D.; Bojin, D.; Demetrescu, I. Comparing three different composites carbon nanotubes/HA on titanium alloys substrate. Full Nanotub. Carbon Nanostruct. 2014, 23, 573-582. [CrossRef]

91. Pantazi, A.; Totu, E.E.; Dorobantu, D.; Cristache, C.M.; Enachescu, M. Poly(methyl metacrylate) nanocomposites for two-piece CAD/CAM solution as an alternative to monolithic removable prosthesis. Mater. Plast. 2018, 55, 634-639. [CrossRef]

92. Hsu, H.-C.; Wu, S.-C.; Yang, C.-H.; Ho, W.-F. ZrO2/hydroxyapatite coating on titanium by electrolytic deposition. J. Mater. Sci. Mater. Electron. 2009, 20, 615-619. [CrossRef]

93. Narayan, R.J. Hydroxyapatite-diamondlike carbon nanocomposite films. Mater. Sci. Eng. C 2005, 25, 398-404. [CrossRef]

94. Chen, C.-C.; Huang, T.-H.; Kao, C.-T.; Ding, S.-J. Characterization of functionally graded hydroxyapatite/titanium composite coatings plasma-sprayed on Ti alloys. J. Biomed. Mater. Res. B Appl. Biomater. 2006, 78, 146-152. [CrossRef] [PubMed]

95. Inagaki, M.; Yokogawa, Y.; Kameyama, T. Apatite/titanium composite coatings on titanium or titanium alloy by RF plasmaspraying process. Thin Solid Films 2001, 386, 222-226. [CrossRef]

96. Braic, M.; Balaceanu, M.; Braic, V.; Vladescu, A.; Pavelescu, G.; Albulescu, M. Synthesis and characterization of TiN, TiAIN and TiN/TiAIN biocompatible coatings. Surf. Coat. Technol. 2005, 200, 1014-1017. [CrossRef]

97. Ionita, D.; Necula, L.; Prodana, M.; Totea, G.; Demetrescu, I. Corrosion of an active antibacterial nanostructured coating on titanium. Rev. Chim. 2018, 69, 1115-1121. [CrossRef]

98. Ionita, D.; Georgescu, D.B.; Prodana, M. Electrochemical and antibacterial properties of an electrodeposited hydroxiapatite bionic film on titanium. Rev. Chim. 2016, 67, 297-301.

99. Montali, A. Antibacterial coating systems. Injury 2006, 37, S81-S86. [CrossRef] [PubMed]

100. Zhao, L.; Chu, P.K.; Zhang, Y.; Wu, Z. Antibacterial coatings on titanium implants. J. Biomed. Mater. Res. B Appl. Biomater. 2009, 91, 470-480. [CrossRef]

101. Chung, D.; Papadakis, S.E.; Yam, K.L. Evaluation of a polymer coating containing triclosan as the antimicrobial layer for packaging materials. Int. J. Food Sci. Technol. 2003, 38, 165-169. [CrossRef]

102. Chen, W.; Liu, Y.; Courtney, H.; Bettenga, M.; Agrawal, C.; Bumgardner, J.; Ong, J. In vitro anti-bacterial and biological properties of magnetron co-sputtered silver-containing hydroxyapatite coating. Biomaterials 2006, 27, 5512-5517. [CrossRef] 
103. Klueh, U.; Wagner, V.; Kelly, S.; Johnson, A.; Bryers, J.D. Efficacy of silver-coated fabric to prevent bacterial colonization and subsequent device-based biofilm formation. J. Biomed. Mater. Res. 2000, 53, 621-631. [CrossRef]

104. Totea, G.; Ionita, D.; Demetrescu, I. Influence of doping ions on the antibacterial activity of biomimetic coating on CoCrMo alloy. J. Bionic Eng. 2015, 12, 583-591. [CrossRef]

105. Van De Belt, H.; Neut, D.; Schenk, W.; Van Horn, J.R.; Van Der Mei, H.C.; Busscher, H.J. Infection of orthopedic implants and the use of antibiotic-loaded bone cements: A review. Acta Orthop. Scand. 2001, 72, 557-571. [CrossRef]

106. Pugach, J.L.; Ditizio, V.; Mittelman, M.W.; Bruce, A.W.; DiCosmo, F.; Khoury, A.E. Antibiotic hydrogel coated foley catheters for prevention of urinary tract infection in a rabbit model. J. Urol. 1999, 162, 883-887. [CrossRef] [PubMed]

107. Li, Z.; Lee, D.; Sheng, X.; Cohen, R.E.; Rubner, M.F. Two-level antibacterial coating with both release-killing and contact-killing capabilities. Langmuir 2006, 22, 9820-9823. [CrossRef] [PubMed]

108. Stoian, A.B.; Surdu-Bob, C.; Anghel, A.; Ionita, D.; Demetrescu, I. Investigation of high voltage anodic plasma (HVAP) Ag-DLC coatings on Ti50Zr with different Ag amounts. Coatings 2019, 9, 792. [CrossRef]

109. Ionita, D.; Golgovici, F.; Mazare, A.; Badulescu, M.; Demetrescu, I.; Pandelea-Dobrovicescu, G.-R. Corrosion and antibacterial characterization of Ag-DLC coatingon a new CoCrNbMoZr dental alloy. Mater. Corros. 2018, 69, 1403-1411. [CrossRef]

110. Grecu, M.; Novac, G.; Ionita, D.; Ungureanu, C. Incorporation of tobramycin biomimetic in hydroxyapatite coating on CoCrMo alloy and its antimicrobial activity. Rev. Chim. 2011, 62, 352-356.

111. Klasen, H. A historical review of the use of silver in the treatment of burns. II. Renewed interest for silver. Burns 2000, 26, 131-138. [CrossRef]

112. Mazare, A.; Anghel, A.; Surdu-Bob, C.; Totea, G.; Demetrescu, I.; Ionita, D. Silver doped diamond-like carbon antibacterial and corrosion resistance coatings on titanium. Thin Solid Films 2018, 657, 16-23. [CrossRef]

113. Ionita, D.; Ungureanu, C.; Demetrescu, I. Electrochemical and antibacterial performance of CoCrMo alloy coated with hydroxyapatite or silver nanoparticles. J. Mater. Eng. Perform. 2013, 22, 3584-3591. [CrossRef]

114. Alta, V.; Bechertb, T.; Steinrückeb, P.; Wagenerc, M.; Seideld, P.; Dingeldeind, E.; Domanne, E.; Schnettlera, R. An in vitro assessment of the antibacterial properties and cytotoxicity of nanoparticulate silver bone cement. Biomaterials 2004, 25, $4383-4391$. [CrossRef]

115. Davis, I.J.; Richards, H.; Mullany, P. Isolation of silver- and antibiotic-resistant Enterobacter cloacae from teeth. Oral Microbiol. Immunol. 2005, 20, 191-194. [CrossRef]

116. Faber, C.; Stallmann, H.P.; Lyaruu, D.M.; Joosten, U.; Von Eiff, C.; Amerongen, A.V.N.; Wuisman, P.I.J.M. Comparable efficacies of the antimicrobial peptide human lactoferrin 1-11 and gentamicin in a chronic methicillin-resistant staphylococcus aureus osteomyelitis model. Antimicrob. Agents Chemother. 2005, 49, 2438-2444. [CrossRef] [PubMed]

117. Gallardomoreno, A.; Pachaolivenza, M.; Saldaña, L.; Perezgiraldo, C.; Bruque, J.M.; Vilaboa, N.; Gonzalezmartin, M. In vitro biocompatibility and bacterial adhesion of physico-chemically modified Ti6Al4V surface by means of UV irradiation. Acta Biomater. 2009, 5, 181-192. [CrossRef] [PubMed]

118. Ehrlich, G.D.; Stoodley, P.; Kathju, S.; Zhao, Y.; McLeod, B.R.; Balaban, N.; Hu, F.Z.; Sotereanos, N.G.; Costerton, J.W.; Stewart, P.S.; et al. Engineering approaches for the detection and control of orthopaedic biofilm infections. Clin. Orthop. Relat. Res. 2005, 437, 59-66. [CrossRef]

119. Suzuki, Y.; Tanihara, M.; Nishimura, Y.; Suzuki, K.; Kakimaru, Y.; Shimizu, Y. A new drug delivery system with controlled release of antibiotic only in the presence of infection. J. Biomed. Mater. Res. 1998, 42, 112-116. [CrossRef]

120. Lin, Z.; Sun, X.; Yang, H. The role of antibacterial metallic elements in simultaneously improving the corrosion resistance and antibacterial activity of magnesium alloys. Mater. Des. 2021, 198, 109350. [CrossRef]

121. Adhikari, J.; Saha, P.; Sinha, A. Surface modification of metallic bone implants-Polymer and polymer-assisted coating for bone in-growth. In Fundamental Biomaterials: Metals; Balakrishnan, P., Sreekala, M.S., Thomas, S., Eds.; Woodhead Publishing: Cambridge, UK, 2018; pp. 299-321.

122. Papaioannou, W.; Gizani, S.; Nassika, M.; Kontou, E.; Nakou, M. Adhesion of streptococcus mutans to different types of brackets. Angle Orthod. 2007, 77, 1090-1095. [CrossRef]

123. Cometa, S.; Bonifacio, M.A.; Mattioli-Belmonte, M.; Sabbatini, L.; De Giglio, E. Electrochemical strategies for titanium implant polymeric coatings: The why and how. Coatings 2019, 9, 268. [CrossRef]

124. Schlosshauer, B.; Dreesmann, L.; Schaller, H.-E.; Sinis, N. Synthetic nerve guide implants in humans: A comprehensive survey. Neurosurgery 2006, 59, 740-748. [CrossRef]

125. Evans, G.R.D.; Brandt, K.; Niederbichler, A.D.; Chauvin, P.; Hermann, S.; Bogle, M.; Otta, L.; Wang, B.; Patrick, C.W. Clinical long-term in vivo evaluation of poly(L-lactic acid) porous conduits for peripheral nerve regeneration. J. Biomater. Sci. Polym. Ed. 2000, 11, 869-878. [CrossRef] [PubMed]

126. Bini, T.B.; Gao, S.; Tan, T.C.; Wang, S.; Lim, A.; Ben Hai, L.; Ramakrishna, S. Electrospun poly(L-lactide-co-glycolide) biodegradable polymer nanofibre tubes for peripheral nerve regeneration. Nanotechnology 2004, 15, 1459-1464. [CrossRef]

127. Dunnen, W.F.A.D.; Meek, M.F.; Robinson, P.H.; Schakernraad, J.M. Peripheral nerve regeneration through P(DLLA- $\varepsilon-C L)$ nerve guides. J. Mater. Sci. Mater. Electron. 1998, 9, 811-814. [CrossRef]

128. Li, S.-T.; Archibald, S.J.; Krarup, C.; Madison, R.D. Peripheral nerve repair with collagen conduits. Clin. Mater. 1992, 9, 195-200. [CrossRef]

129. Li, B.; Logan, B. Bacterial adhesion to glass and metal-oxide surfaces. Colloids Surf. B Biointerfaces 2004, 36, 81-90. [CrossRef] 
130. Park, K.D.; Kim, Y.S.; Han, D.K.; Lee, E.H.B.; Suh, H.; Choi, K.S. Bacterial adhesion on PEG modified polyurethane surfaces. Biomaterials 1998, 19, 851-859. [CrossRef]

131. Roosjen, A.; Kaper, H.J.; Van Der Mei, H.C.; Norde, W.; Busscher, H.J. Inhibition of adhesion of yeasts and bacteria by poly(ethylene oxide)-brushes on glass in a parallel plate flow chamber. Microbiology 2003, 149, 3239-3246. [CrossRef]

132. Kawabe, A.; Nakagawa, I.; Kanno, Z.; Tsutsumi, Y.; Hanawa, T.; Ono, T. Evaluation of biofilm formation in the presence of saliva on poly(ethylene glycol)deposited titanium. Dent. Mater. J. 2014, 33, 638-647. [CrossRef] [PubMed]

133. Roosjen, A.; Busscher, H.J.; Norde, W.; Van Der Mei, H.C. Bacterial factors influencing adhesion of Pseudomonas aeruginosa strains to a poly(ethylene oxide) brush. Microbiology 2006, 152, 2673-2682. [CrossRef] [PubMed]

134. Razatos, A.; Ong, Y.-L.; Boulay, F.; Elbert, D.L.; Hubbell, J.A.; Sharma, M.M.; Georgiou, G. Force measurements between bacteria and poly(ethylene glycol)-coated surfaces. Langmuir 2000, 16, 9155-9158. [CrossRef]

135. Demetrescu, I.; Dumitriu, C.; Totea, G.; Nica, C.I.; Dinischiotu, A.; Ionita, D. Zwitterionic cysteine drug coating influence in functionalization of implantable Ti50Zr alloy for antibacterial, biocompatibility and stability properties. Pharmaceutics 2018, 10, 220. [CrossRef]

136. Desai, N.P.; Hossainy, S.F.; Hubbell, J.A. Surface-immobilized polyethylene oxide for bacterial repellence. Biomaterials 1992, 13, 417-420. [CrossRef]

137. Chu, P.K.; Chen, J.Y.; Wang, L.P.; Huang, N. Plasma-surface modification of biomaterials. Mater. Sci. Eng. R Rep. 2002, 36, 143-206. [CrossRef]

138. Cools, P.; De Geyter, N.; Vanderleyden, E.; Dubruel, P.; Morent, R. Surface analysis of titanium cleaning and activation processes: Non-thermal plasma versus other techniques. Plasma Chem. Plasma Process. 2014, 34, 917-932. [CrossRef]

139. Zhang, S.; Awaja, F.; James, N.; McKenzie, D.R.; Ruys, A.J. Autohesion of plasma treated semi-crystalline PEEK: Comparative study of argon, nitrogen and oxygen treatments. Colloids Surf. A Physicochem. Eng. Asp. 2011, 374, 88-95. [CrossRef]

140. Kim, M.; Yang, S.; Boo, J.-H.; Han, J. Surface treatment of metals using an atmospheric pressure plasma jet and their surface characteristics. Surf. Coat. Technol. 2003, 174-175, 839-844. [CrossRef]

141. Zhou, M.; Heinze, J. Electropolymerization of pyrrole and electrochemical study of polypyrrole: 1 . Evidence for structural diversity of polypyrrole. Electrochim. Acta 1999, 44, 1733-1748. [CrossRef]

142. Krishnan, S.; Weinman, C.J.; Ober, C.K. Advances in polymers for anti-biofouling surfaces. J. Mater. Chem. 2008, 18, 3405-3413. [CrossRef]

143. Szleifer, I. Protein adsorption on surfaces with grafted polymers. Biophys. J. 1997, 72, 595-612. [CrossRef]

144. Xie, F.; Deng, X.; Kratzer, D.; Cheng, K.C.K.; Friedmann, C.; Qi, S.; Solorio, L.; Lahann, J. Backbone-degradable polymers prepared by chemical vapor deposition. Angew. Chem. Int. Ed. 2016, 56, 203-207. [CrossRef]

145. Nathanael, A.J.; Oh, T.H. Biopolymer coatings for biomedical applications. Polymers 2020, 12, 3061. [CrossRef] [PubMed]

146. Tian, P.; Liu, X. Surface modification of biodegradable magnesium and its alloys for biomedical applications. Regen. Biomater. 2015, 2, 135-151. [CrossRef] [PubMed]

147. Vardaki, M.; Ionita, D.; Stoian, A.B.; Demetrescu, I. Increasing corrosion resistance of a ZrTi alloy with a bioinspired coating with low porosity. Mater. Corros. 2017, 68, 988-994. [CrossRef]

148. Stoian, A.B.; Demetrescu, I.; Ionita, D. Nanotubes and nano pores with chitosan construct on TiZr serving as drug reservoir. Colloids Surf. B Biointerfaces 2020, 185, 110535. [CrossRef] [PubMed]

149. Szewczenko, J.; Kajzer, W.; Kajzer, A.; Basiaga, M.; Kaczmarek, M.; Antonowicz, M.; Nowińska, K.; Jaworska, J.; Jelonek, K.; Kasperczyk, J. Biodegradable polymer coatings on Ti6Al7Nb alloy. Acta Bioeng. Biomech. 2019, 21, 83-92. [CrossRef]

150. Moses, A.; Pulapura, S.; Ge, Q.; Nethula, S.; Shatova, I.; Rajaram, A. Biodegradable, Polymer Coverings for Breast Implants. US Patent Appl. 8911765, 16 December 2014. Available online: https:/ / www.freepatentsonline.com/8911765.html (accessed on 23 April 2021).

151. Conte, R.; Di Salle, A.; Riccitiello, F.; Petillo, O.; Peluso, G.; Calarco, A. Biodegradable polymers in dental tissue engineering and regeneration. AIMS Mater. Sci. 2018, 5, 1073-1101. [CrossRef] 